\title{
Basic First Aid Knowledge Levels of Students of the Vocational School of Health Services
}

\author{
Ufuk Kaya' (1), Meryem Güvenir' (1), Tuğçe Balcı Okcanoğlu' (D), Emrah Güler² (D), Aslı Aykaç ${ }^{3}$ (1) \\ 'Near East University, Vocational School of Health Services, Nicosia, Cyprus \\ ${ }^{2}$ Department of Microbiology, Near East University, School of Medicine, Nicosia, Cyprus \\ ${ }^{3}$ Department of Biophysics, Near East University, School of Medicine, Nicosia, Cyprus
}

ORCID IDs of the authors: U.K. 0000-0002-09II-4886; M.G. 0000-0002-9702-9947; T.B.O. 0000-0003-0613-765X; E.G. 0000-0002-I635005I; A.A. 0000-0002-4885-5070.

Cite this article as: Kaya U, Güvenir M, Balcı Okcanoğlu T, Güler E, Aykaç A. Basic First Aid Knowledge Levels of Students of the Vocational School of Health Services. Cyprus J Med Sci 2019; 4(3): 173-6.

\section{BACKGROUND/AIMS}

In this descriptive study, our aim was to evaluate the knowledge on basic first aid of students attending the Vocational School of Health Services.

\section{MATERIALS and METHODS}

The study group consisted of 296 students in 23 departments of the Vocational School of Health Services. A total of 31 questions administered via the Students Introductory Information Form and Basic First Aid Questionnaire were answered by students who agreed to participate voluntarily in the research. The analyses were conducted using the Statistical Package for the Social Sciences (SPSS) Version I3.0 (IBM Corp;; Armonk, NY, USA) package program in the computer environment with a $p$-value $<0.05$ determining the significance level.

\section{RESULTS}

It has been determined that $88.9 \%$ of the students had previously received basic education on first aid, and $50 \%$ of the students believed that their knowledge in this area was sufficient. The basic first aid knowledge score of the students was calculated as 76.03. The most correctly answered question was regarding the definition of basic first aid, while the least correctly answered question was on the chest compression rates.

\section{CONCLUSION}

In addition to theoretical courses, if time spent practicing with models in applied courses is not sufficient; it can prevent the students from reinforcing their knowledge. However, in addition to applications during the internship training, professional practice can help the students to acquire the required knowledge.

Keywords: Education, first aid, health services, knowledge

\section{INTRODUCTION}

In cases involving accidents or life-threatening emergencies, first aid means that a person (or persons) at the scene provides medical assistance without any medications to save the victims life and/or to prevent the situation from getting worse until the professional health workers arrive at the scene $(\mathrm{I}-6)$. In cases when first aid is required, a successfully applied first aid intervention can be lifesaving (3). At any moment in life, an unexpected situation may happen, involving an accident or illness that could require first aid. In such cases, there may not be professional health workers at the scene. In these emergency situations, a health worker may not be immediately available to provide assistance, which means that a member of the public may have to provide first aid in case of an accident or injury, and anyone familiar with the principles of first aid could provide assistance (7). The ability to administered first aid to oneself or to another person is very important because it can contribute to increased survival rates, the prevention of injury, and the healing process (2). Considering all these situations, individuals who provide first aid apply life saving measures until emergency health workers reach the scene, and they play an important role in emergency health services (3).

Presented in: This study was presented as a poster presentation at the $29^{\text {th }}$ National Biochemistry Congress of TBD International Biochemistry Congress held on 26-30 October 2018, Bodrum, Muğla, Turkey. 
As the locations in which accidents requiring first aid happen are frequently crowded, it is natural to assume that universities are among these environments. Although first aid lessons are a compulsory part of the curriculum in the faculties and schools providing health-related education, the number of studies on whether the theoretical and/or practical knowledge levels of the students receiving first aid lessons/education are sufficient is limited (I, 2). In fact, it is important that individuals understand and practice first aid, which can be beneficial for them, their relatives, and even society (3).

The aim of this study was to evaluate the theoretical knowledge level of second-grade students attending the Vocational School of Health Services of a private university in the Turkish Republic of Northern Cyprus. The answers were sought to the following research questions:

I. What is an average score of the students' knowledge about basic first aid?

II. Is there a difference on basic first aid knowledge levels between the basic first aid course and the students taking courses and not taking courses?

III. What are the differences between the students who find their knowledge in first aid to be sufficient and those who feel that they are lacking it?

\section{MATERIAL and METHODS}

The research population consisted of 296 second-grade students attending the Vocational School of Health Services of a private university in the Turkish Republic of Northern Cyprus during the 2017-2018 spring semester. In the descriptive study, the sample selection was made by choosing $50 \%$ of students, and all participants were reached.

Prior to the study, written permission was obtained from the Directorate of Vocational School of Health Services and from the Ethics Review Board (Near East University Scientific Research and Ethics Committee, 31.05.2018/607). Verbal consent was obtained from the students who accepted to participate voluntarily in the data collection stage.

Data were collected by the researchers using the Student Introductory Information Form and basic first aid questions developed in accordance with the literature. In the Student Introductory Information Form, 10 questions on socio-demographic characteristics such as age and gender, education on basic first aid, participation in activities within the university and/or external, basic first aid practice situation and self-sufficiency in relation to basic first aid were asked.

A total of 21 questions were asked about basic first aid. The questions included the definition of the subject, adult and child basic life support, respiratory blockages, positions, bleeding, fractures, dislocations and sprains, epileptic seizures, penetrating and cutting tool injuries, burns, freezing, tourniquet application, security measures, animal bites, insect stings, and limb ruptures.

\section{Statistical Analysis}

Data were analyzed using the Statistical Package for the Social Sciences (SPSS) Version I3.0 (IBM Corp.; Armonk, NY, USA).
Pearson's chi-squared test and Fisher's exact test were used to compare the number of correct answers among students. A $p$-value $<0.05$ was considered significant.

\section{RESULTS}

The mean age of 296 students was $21.91 \pm 2.41 ; 36.1 \%$ ( $n=107$ ) were female, and $63.9 \%(n=189)$ were male. In Table I, it can be seen that $88.9 \%$ of the students received basic first aid education. It was found that the ratio of students who found their knowledge to be sufficient in basic first aid was equal to the ratio of students who found their knowledge to be insufficient ( $n=148 ; 50 \%$; in both groups).

In our study, the mean first aid score of the students was evalvated. Accordingly, it was determined that their basic first aid knowledge point average was 76.03. When the average score of basic first aid knowledge according to gender is examined, it is found that females had a score of 76.46, and the score of males was 75.79. While the average knowledge score of the students who were previously trained about basic first aid was 76.0l, it was determined that the average score of the students who found their knowledge to be sufficient was 77.47 (Table 2).

Table 3 shows the correct and incorrect response rates of the subjects whose basic first aid knowledge was examined. While the ratio of answering the questions is high, the issues of chest compressions, airway obstruction, tourniquet application, and shock position had the highest number of incorrect answers.

\section{TABLE I. Descriptive properties $(n=296)$}

Descriptive properties

Taking basic first aid education

Finding one's knowledge sufficient about basic first aid

No

TABLE 2. Info points averages

\begin{tabular}{|c|c|c|}
\hline $\begin{array}{l}\text { Basic first aid knowledge } \\
\text { average score }\end{array}$ & $\mathbf{n}$ & Mean score \\
\hline \multicolumn{3}{|c|}{ Knowledge point average by gender } \\
\hline Woman & 107 & 76.46 \\
\hline Man & 189 & 75.79 \\
\hline \multicolumn{3}{|c|}{$\begin{array}{l}\text { The average knowledge score for the students } \\
\text { who were trained and not trained in basic first aid }\end{array}$} \\
\hline Yes & 263 & 76.01 \\
\hline No & 33 & 76.19 \\
\hline \multicolumn{3}{|c|}{$\begin{array}{l}\text { The average knowledge score of the students who } \\
\text { find themselves sufficiently knowledge able regarding } \\
\text { basic first aid }\end{array}$} \\
\hline Yes & 148 & 77.47 \\
\hline No & 148 & 74.58 \\
\hline
\end{tabular}




\begin{tabular}{|c|c|c|c|c|}
\hline \multirow[b]{2}{*}{ Basic first aid questions } & \multicolumn{2}{|c|}{ True } & \multicolumn{2}{|c|}{ False } \\
\hline & $\mathbf{n}$ & $\%$ & n & $\%$ \\
\hline Definition of basic first aid & 288 & 97.3 & 8 & 2.7 \\
\hline Chest compression rates & 64 & 21.6 & 232 & 78.4 \\
\hline Baby consciousness control & 241 & 81.4 & 55 & 18.6 \\
\hline Respiratory tract blockages & 121 & 40.9 & 175 & 59.1 \\
\hline Coma position & 236 & 79.7 & 60 & 20.3 \\
\hline External bleeding & 266 & 89.9 & 30 & I0.1 \\
\hline Fractures, dislocations, and sprains & 226 & 76.4 & 70 & 23.6 \\
\hline Epileptic seizure & 277 & 93.6 & 19 & 6.4 \\
\hline Penetrating, cutting tool injuries & 264 & 89.2 & 32 & 10.8 \\
\hline Burn & 230 & 77.7 & 66 & 22.3 \\
\hline Tourniquet application & 95 & 32.1 & 201 & 67.9 \\
\hline Nasal bleeding & 252 & 85.1 & 44 & 14.9 \\
\hline Freezing & 276 & 93.2 & 20 & 6.8 \\
\hline Safety precautions & 271 & 91.6 & 25 & 8.4 \\
\hline Safe zone & 254 & 85.8 & 42 & 14.2 \\
\hline Animal bites, insect stings & 221 & 74.7 & 75 & 25.3 \\
\hline Shock position & 102 & 34.5 & 194 & 65.5 \\
\hline Limb ruptures & 253 & 85.5 & 43 & 14.5 \\
\hline Pediatric cardiac massage & 285 & 96.3 & II & 3.7 \\
\hline Chest compression/artificial respiration rates & 235 & 79.4 & 61 & 20.6 \\
\hline Artificial respiration & 269 & 90.9 & 27 & 9.1 \\
\hline
\end{tabular}

TABLE 4. Distribution of basic first aid questions in students who find their knowledge about first aid sufficient/insufficient

\begin{tabular}{|lccccccc|} 
& \multicolumn{2}{c}{ Sufficient } & & \multicolumn{3}{c}{ Insufficient } & \\
\cline { 2 - 3 } Basic first aid question & True & False & & True & False & p \\
\hline Baby consciousness control & $13 \mid$ & 17 & & 110 & 38 & 0.002 \\
Animal bites, insect stings & 120 & 28 & & 101 & 48 & 0.011 \\
$\begin{array}{l}\text { Chest compression/artificial } \\
\text { respiration rates }\end{array}$ & 127 & 21 & & 108 & 40 & 0.006 \\
\hline
\end{tabular}

\begin{tabular}{|c|c|c|c|c|c|}
\hline \multirow[b]{2}{*}{ Basic first aid question } & \multicolumn{2}{|c|}{ Women } & \multicolumn{2}{|c|}{ Men } & \multirow[b]{2}{*}{$p$} \\
\hline & True & False & True & False & \\
\hline External bleeding & 105 & 2 & 161 & 28 & 0.00 \\
\hline Nasal bleeding & 99 & 8 & 153 & 36 & 0.007 \\
\hline
\end{tabular}

In Table 4, the rates of students who did not find their knowledge about first aid sufficient/insufficient according to these data, there was a statistically significant difference in the topics covering the baby consciousness control, animal bites, insect bites, and chest compression/artificial respiration rates $(p<0.05)$.

Table 5 shows the rates that differed significantly in the answers of students evaluated according to their gender. Thus, there was a statistically significant difference in relation to external bleeding and nose bleeding $(p<0.05)$.

\section{DISCUSSION}

Similar to the results of a study conducted to determine the level of knowledge and factors affecting the basic first aid knowledge in a vocational school of health services students, in our study, the rate of correct answers to 2 l questions asked to measure the knowledge level of the students about basic first aid was highly correct (2). In the results of a study conducted on medical students, it was determined that the students did not respond correctly to all questions about first aid $(8,9)$. In our results, it was found that there was a lack of information about these subjects based on the students' incorrect answers to questions regarding basic first aid, including the rate of chest compressions applied per minute in the active heart massage, first aid in respiratory tract obstructions, tourniquet application, and the shock position. As stated by Büyükkayacı Duman et al. (I), it is thought that students lack knowledge in relation to some questions, and this means they cannot fully comprehend the situation/event. In the study on the first aid knowledge levels of class teachers, it was found that $95.9 \%$ of the teachers did not know how to perform cardiac massage (7). According to the findings of a similar study, university students have serious shortcomings in basic subjects such as chest compression and artificial respiration. The reason for this is the absence of courses with the first aid content in the departments outside the health sector. In our study, the most incorrectly answered question was determined as the one related to the rate of chest compression for an effective cardiac massage. The research universe comprised students attending a vocational school of health services. Therefore, this indicates that the rate of chest compression requires more practice and observation rather than theoretical information.

In studies conducted on different audiences, such as a police school, vocational school students, and non-physicians, basic first aid was the most correctly answered question in the research conducted by different researchers (96.7\%, 88.2\%, 91.8\%) $(2,10,11)$. According to the results of our study, the basic first aid definition question was answered correctly with a rate of $97.3 \%$, which is similar to the literature.

In our study, the average score for the basic first aid knowledge of the students was determined to be 76.03. Similar to the results of our study, in a study that involved the first-year medical students, the average score for basic first aid was 68.0 (9). In contrast to these results, this rate was determined to be 5.96 in a study conducted with forestry and forestry vocational school students (3). This ratio was determined to be $42.42 \pm 16.44$ in the results of a first aid study on prisoners (12). In the light of the information in the literature, it can be thought that education, and particularly the education received in the field of health, have a significant effect on the first aid knowledge point average. In addition, studies determining the level of first aid knowledge of students, nurses, or policemen are also important to identify educational deficiencies related to first aid.

In a study that examined differences in first aid knowledge according to gender, a higher number of female students correctly answered the statement related to "cuts and dirty wounds are washed with soapy water, and tincture is applied" in comparison to male students. In the same study, in response to a question stating that "for patients poisoned with caustic substances such as bleach or oil, vomiting should be induced immediately," it was 
found that females answered this question correctly more frequently (I). According to our study results, the questions that were answered correctly less frequently by both male and female students were related to coma position $(p<0.319)$, fractures, dislocations, and sprains $(p<0.443)$, penetrating and cutting tool injuries $(p<0.54 \mid)$, burns $(p<0.589)$, and limb fractures $(p<0.235)$ (Table 3$)$.

A total of $1.1 \%$ of students who participated in the research stated that they had not received the first aid training. In a study by Usta et al. (3), 44\% of the participants claimed that they had no training, and Nayir et al. (13) determined that teachers had knowledge of first aid, while $61.5 \%$ of the participants did not receive first aid training. According to the literature, the number of people who received first aid training in our study is high (88.9\%). The reasons of this could be that first aid is a basic and compulsory course in many departments related to vocational schools of health services. The expansion of first aid training will contribute to an increase in the first aid knowledge levels.

This study was limited to the second-year students attending the Vocational School of Health Services. According to the findings obtained from the study, when the average of the students' response to the questions about first aid is taken into consideration, the correct response rates are high for many questions. However, it is important to note that some students also answered them incorrectly. The reasons for these incorrect answers could be that the student was not attending the Vocational School of Health Services and/or had moved from another part of another faculty to the Vocational School.

In non-health departments where first aid courses are not compulsory, it is possible to provide basic first aid training to students. The incorrect answers of students to the basic first questions can be analyzed further to determine what information they are lacking and to take corrective action in a timely manner. Considering that some of the basic first aid questions have been incorrectly answered by the students, it is necessary to examine the problems they have missed and correct them early. In this context, to add the first aid class to the departments that are not obligatory, to increase the interest in the class, to increase the visual and audio materials, to organize first-aid-related seminars such as symposiums and/or courses during the training periods, to increase the basic first aid hours, and to provide students with a certificate of achievement or certifications are important. In addition, it will be possible to increase the awareness of the students regarding the fact that receiving a first aid training in any period of their education will have a direct impact on their knowledge and could potentially save lives.

Ethics Committee Approval: Ethics committee approval was received for this study from the ethics committee of Near East University Scientific Research and Ethics Committee (31.05.2018/607).
Informed Consent: Verbal informed consent was obtained fromstudents who participated in this study.

Peer-review: Externally peer-reviewed.

Author Contributions: Concept - U.K., M.G., T.B.O., E.G., A.A.; Design - U.K., M.G., T.B.O., E.G., A.A.; Supervision - U.K., M.G., T.B.O., A.A.; Resources U.K.; Data Collection and/or Processing - U.K., E.G., A.A.; Analysis and/or Interpretation - U.K., E.G., A.A.; Literature Search - U.K., M.G., T.B.O., A.A.; Writing Manuscript - U.K., A.A.; Critical Review - U.K., A.A.

Conflict of Interest: The authors have no conflicts of interest to declare.

Financial Disclosure: The authors declared that this study has received no financial support.

\section{REFERENCES}

I. Büyükkayacı Duman N, Koçak C, Sözen C. First aid knowledge levels of university students and the factors affecting these levels. Hitit University Social Sciences Institute Journal 2013; 6(I): 57-70.

2. Barutcu CD, Dilek GA, Çakmak Ö, Köksoy S, Polat M. Level of knowledge and factors affecting first aid in vocational high school students. IJCS 2017; 10(3): 1563-8.

3. Usta G, Küçük U, Torpuș K. An investigation into vocational school students' first aid knowledge and attitudes. HOD 20I7; 2(2): 67-77.

4. Al-Musa HM, Bharti RK, Alsamghan AS, Asiri M, Alqagtani MS, Al-Qahtani D, et al. Knowledge of first aid skills among medical students in King Khalid University, Abha, Saudi Arabia. Int J Sci Res 2017; IO(I): I-6.

5. Altındiș S, Tok Ș, Aslan FG, Pilavcı Adıgül M, Ekerbiçer HC , Altındiș $M$. Assessment of first aid knowledge level of university students. Sakarya Tıp Dergisi 2017; 7(3): 125-30. [CrossRef]

6. Khatatbeh M. First aid knowledge among university students in Jordan. Int J Prev Med 2016;7: 24. [CrossRef]

7. Erkan M, Göz F. Determination of the teachers' level of knowledge about the first aid subject. Atatürk Üniversitesi Hemșirelik Yüksekokulu Dergisi 2006; 9(4): 63-8.

8. Abbas A, Bukhari S, Ahmad F. Knowledge of first aid and basic life support amongst medical students: A comparison between trained and un-trained students. J Pak Med Assoc 2011; 6I(6): 613-6.

9. Almoammar NA, Fathalla A, Alotaibi FF, Alshahrani KM, Alanazi $A M$, Alwarni $A A$, et al. Assessing the level of first-aid knowledge among undergraduate medical students in King Sud University. Int J Pharm Red Allied Sci 2018; 6(I): 58-63.

10. Polat SA, Turaci G. First aid knowledge and attitude of a police training school's students. AÜTD 2003; 35: 27-32.

II. Dündar C, Sünter T, Coșkun M, Topbaș M, Pekșen Y. The evaluation of health workers' knowledge levels about first aid working at primary health care units in Samsun. OMÜ Tıp Dergisi 1999; 16(2): II3-9.

12. Köksoy S, Öncü E, Șermet Ș, Sungur MA. First aid knowledge levels of prison inmates. Tr J Emerg Med 20I2; I2(I): 20-4. [CrossRef]

13. Nayir T, Uskun E, Türkoğlu H, Uzun E, Öztürk M, Kișioğlu AN. The first aid knowledge levels and attitude of the teachers who work in Isparta city center. SDÜ Tıp Fak Derg 20II; 18(4): 123-7. 